\title{
Studies on service free semiochemical mediated technologies to control red palm weevil Rhynchophorus ferrugineus Olivier based on trials in Saudi Arabia and India
}

\author{
J.R. Faleiro ${ }^{1}$, Abdul Moneim Al-Shawaf ${ }^{2}$, H.A.F. El-Shafie ${ }^{3}$ and Samir Pai Raikar ${ }^{4}$ \\ (1) Food and Agriculture Organization of the UN, Goa, India, email: jrfaleiro@yahoo.co.in; (2) Centre of Date Palm and \\ Dates, P.O. Box 43, Al-Hassa-31982, Saudi Arabia; (3) Date Palm Research Center of Excellence, King Faisal University, \\ P.O. Box 400, Al Ahsaa-31982, Kingdom of Saudi Arabia; (4) Godrej Agrovet Limited, Valpoi, Goa, India
}

\begin{abstract}
Faleiro, J.R., A.-M. Al-Shawaf, H.A.F. El-Shafie and S. Pai Raikar. 2019. Studies on service free semiochemical mediated technologies to control red palm weevil Rhynchophorus ferrugineus Olivier based on trials in Saudi Arabia and India. Arab Journal of Plant Protection, 37(2): 136-142.

The red palm weevil (RPW) Rhynchophorus ferrugineus Olivier (Coleoptera: Curculionidae) is key invasive pest causing wide spread damage to date palm Phoenix dactylifera L. in the middle east and north Africa where it is designated as a category-1 pest by the Food and Agriculture Organization of the UN. Food baited pheromone (ferrugineol) traps have been widely used to both monitor and mass trap adult RPW in palm based agro-ecosystems all over the world since early 1990s. However, due to inherent problems associated with the periodic replacement of the food bait and water (trap servicing) in the traditional pheromone trap, pheromone trapping in area wide IPM programmes to control the pest have become costly and unsustainable. This article presents an overview of the field studies were carried out in Saudi Arabia and India to evaluate service-less trapping techniques of RPW using i) trap free "Attract and Kill" technology and ii) dry trap designed on the principle of electromagnetic communication and olfaction in insects. While "Attract and Kill" studies were carried out in three locations in the Kingdom of Saudi Arabia and one location in India, the dry trap was tested only in Saudi Arabia. Multiple field studies to evaluate "Attract and Kill" tools against RPW showed that large numbers of the adult weevils could be eliminated without the additional effort involved in the periodic servicing associated with the traditional food baited pheromone traps. Furthermore, comparative efficiency of the service-less dry pheromone trap against the traditional food baited traps, revealed that weevil captures in both the dry trap and the food baited traps were statistically similar. The above semiochemical mediated techniques offer sustainable trapping solutions for RPW management, and could be deployed especially in areas where the trap density has to be increased due to high weevil activity.

Keywords: Rhynchophorus ferrugineus, semiochemicals, attract and kill, dry trap, repellents.
\end{abstract}

\section{Introduction}

The red palm weevil (RPW), Rhynchophorus ferrugineus Olivier (Coleoptera: Curculionidae), is an internal tissue borer attacking palm trees in diverse agro-ecosystems worldwide (Abraham et al., 1998; Milosavljević et al., 2019). During the last three decades, its host range has extended to 40 palm species from only four palm species it was reported to attack during the 1960s. This ten-fold leap in the host range and also increasing geographical expanse of RPW has been mainly after it gained foot hold on date palm Phoenix dactylifera $\mathrm{L}$. in the Middle-East during the mid1980s, where it entered and spread through infested planting material (Al-Dosary et al., 2016; Giblin-Davis et al., 2013). Palms transported within national and across international boundaries for farming and ornamental gardening is the main cause for the spread of this hidden pest which moves through infested planting material (Faleiro, 2006; Milosavljević et al., 2019). Inadequate phytosanitary measures and weak enforcement of quarantine regulations at the national, regional and international levels, coupled with constraints in early detection of infested palms due to lack of efficient and easy to use RPW detection devices, along with the inability of known biological control agents like entomopathogenic nematodes and fungi (EPNs/EPFs) to attain and sustain desired control levels of the pest in the field makes RPW control extremely difficult and challenging (Dembilio and Jacas, 2012; Faleiro, 2006; FAO, 2017).

At the farm level, RPW control mainly revolves around pheromone (ferrugineol) trapping, visual detection of infested palms, preventive and curative chemical treatments, and eradication (removal) of severely infested palms. Foodbaited RPW pheromone traps are used both for monitoring and also mass trapping the pest (Faleiro, 2006). However, regular renewal of the food bait and water in the traditional RPW pheromone that are commonly used trap makes trapping costly and unsustainable in the long run.

\section{Background}

The oldest form of communication among living organisms in the biosphere is through chemical cues. These cues, generally termed as behaviour modifying compounds (BMS) or semiochemicals, have been used for insect pest management. Insect sex pheromones are widely used for the management Lepidopteran insect pests, while aggregation pheromones are commonly used to manage Coleopteran pests (Wyatt, 2003). Due to their natural origin, low persistency in the environment, and species specificity semiochemicals are considered safe and environmentally friendly molecules that are harmless on non-target organisms (Horowitz et al., 2009). Despite general progress in chemical

http://dx.doi.org/10.22268/AJPP-037.2.136142

(C) 2019 Arab Society for Plant Protection الجمعية العربية لوقاية النبات 
ecology and potential of semiochemicals, their commercial exploitation in date plantations has been slow. Effective attractants are known for only a few date pests and even for those, their use is usually limited to monitoring (Soroker $e t$ al., 2015).

Prior to the synthesis of the RPW aggregation pheromone (ferrugineol) in 1993, trapping of adult weevils in coconut was carried out using food baits, fermenting palm wood, split coconut logs smeared with fresh toddy (Abraham and Kurian, 1975). With the characterization and synthesis of the male produced aggregation pheromone by Hallett et al., 1993, food baited bucket pheromone traps have been widely used in both, RPW monitoring and mass trapping programs, where weevil captures are female dominant (Faleiro, 2006). Insect-produced chemicals generate synergy for attraction with host plants, especially in the order Coleoptera (Borden, 1985) and therefore, the RPW pheromone (ferrugineol: 4-methyl-5-nonanol) when used in association with a food bait (dates, sugarcane, banana etc.) acts in synergy to enhance weevil captures, as compared to when the pheromone and food bait are used separately (Hallett et al., 1999; Oehlschlager, 2016). In this respect, the chemical co-attractant (ethyl acetate) when used in RPW pheromone traps is known to increase weevil captures (Oehlschlager, 2016). Ferrugineol in association with $10 \%$ of its ketone derivative (ferrugineone) is also known to enhance captures (Abozuhairah et al., 1996). Co-attractants based on fermenting compounds, ethyl acetate and ethanol, could improve the attractant level of ferrugineol and potentially replace non-standardised natural kairomones in RPW trapping systems (Vacas et al., 2016).

Although olfactometer assays have shown that RPW pheromone trapping accounts less than $40 \%$ of the population (El-Shafie and Faleiro, 2017), trap captured female weevils are known to be young, gravid and fertile which helps to curtail the build-up of the pest in the field (Faleiro et al., 2003). However, foods baited pheromone traps have to be regularly serviced, when the food bait and water has to be renewed, which is costly and not sustainable in the long run especially in an area-wide operation involving several hundred traps. Besides trap servicing, recording of weevil captures is essential in decision making and validation of RPW control programs. In this context, it is essential to have smart trapping devices for the efficient management of RPW (Aldhryhim and Al-Ayedh, 2015). RPW semiochemical mediated technologies of the future therefore need to focus on the development of technologies that not only eliminate the need of trap servicing and develop lures that stand-alone but also which could be deployed in a smart trapping device for the overall improvement in the trapping efficiency, data collection and transmission (ElShafie and Faleiro, 2017).

This paper looks at three service-free RPW semiochemical mediated technologies viz. i) attract and kill, ii) dry pheromone traps, and iii) RPW repellents tested in Saudi Arabia and India.

\section{Overview of service-free RPW semiochemical mediated technologies}

Attract and Kill - In Attract and Kill (A\&K), the insect pest attracted by a semiochemical (pheromone) lure is not "entrapped" at the source of the attractant as in mass trapping, but instead the insect is subjected to a killing agent, which eliminates affected individuals from the population after a short period (El-Sayed et al., 2009). A\&K technique is used to control insect pests in a wide range of crops. Brown marmorated stink bug Halyomorpha halys, an invasive, polyphagous insect that causes serious economic injury in particular to specialty crops like apple in the United States is an important example where this technique is used. Several case studies in which $A \& \mathrm{~K}$ has been used with the aim of long-term pest management include pink bollworm, Egyptian cotton leaf worm, codling moth, apple maggot, biting flies, bark beetles, and the eradication of invasive tephritid fruit flies and boll weevils (Camelo et al., 2007; ElSayed et al., 2009; Hossain et al., 2005; Marfa-Neto et al., 2014; Mazomenos et al., 2002; Morrison et al., 2015). The technique is used in integration with other IPM methods.

In the case of RPW, the potential of using $A \& K$ as a component of the RPW-IPM strategy was first studied with a commercial formulation (Hook-RPW ${ }^{\mathrm{TM}}$ : $15 \%$ ferrugineol and 5\% cypermethrin) by El-Shafie et al. (2011). Subsequently, extensive field trials were carried out in Saudi Arabia and India with A\&K systems (Hook-RPW ${ }^{\mathrm{TM}}$; Smart Ferrolure $^{\mathrm{TM}}$ ).

A\&K formulation against RPW developed by ISCA Technologies, USA (Hook-RPW ${ }^{\mathrm{TM}}$ ) was extensively field tested in date palm in Saudi Arabia; while A\&K systems against RPW by Chem Tica International, Costa Rica (Smart Ferrolure $^{\mathrm{TM}}$ ) were tested for palm protection against RPW in large field trials in date and oil palm plantations in Saudi Arabia and India, respectively (Faleiro et al., 2016a; Faleiro et al., 2016b).

Dry traps - Stand-alone RPW pheromone traps without the food bait and water have been advocated in the past (ElShafie and Faleiro, 2017). This will substantially cut the cost of sustaining and replenishing the food bait and water associated with the traditional RPW food baited pheromone traps commonly used in RPW-IPM programs. The Electrap $^{\mathrm{TM}}$ is an advancement in this direction and offers a sustainable service-less trapping option for RPW especially in areas where the trap density has to be increased due to high weevil activity. The Electrap ${ }^{\mathrm{TM}}$ functions on the principle that insects communicate by radiations emitted from oscillating molecules (Al-Saroj et al., 2017).

RPW repellents - The possibility of identifying and deploying insect repellents with pheromones in an area-wide programme involving a push-pull strategy could open a new semiochemical mediated strategy for the sustainable management of RPW. $\alpha$-pinene, singly or in combination with methyl salicylate or menthone has been identified as a potential RPW repellent (Guarino et al., 2013). Further studies are necessary to identify RPW repellents and quantify the extent of palm protection RPW repellents could provide. 

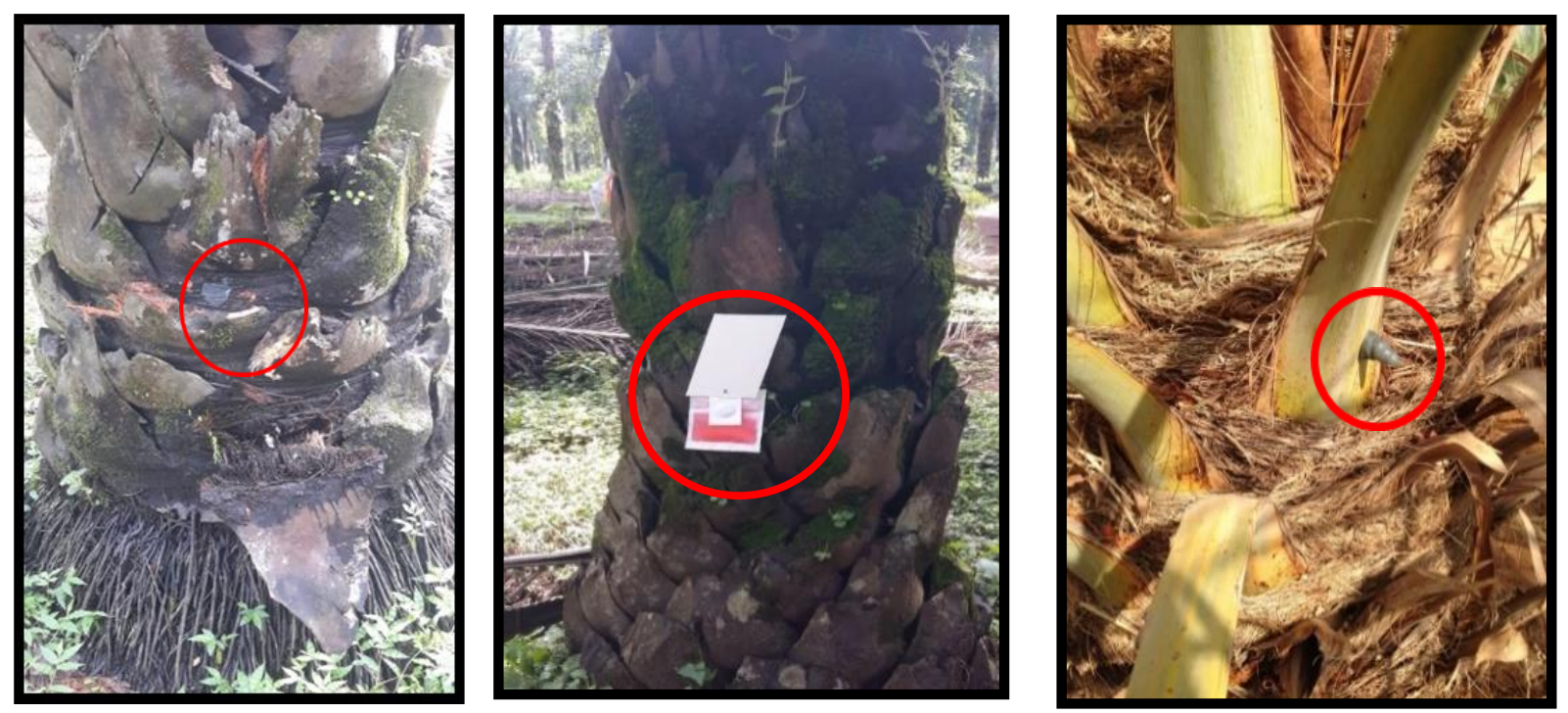

Figure 1. RPW attract and kill systems; Smart Ferrolure paste (left) with a dead weevil and Card device (middle), Hook RPW Dollop (right)

\section{Field trials on service-free RPW semiochemical mediated technologies in Saudi Arabia and India}

Attract and Kill - In a field trial in Al-Qassim, Saudi Arabia, Hook-RPW ${ }^{\mathrm{TM}}$ (ISCA Technologies, California, USA) was applied as two- $4 \mathrm{~g}$ dollops of Hook-RPW ${ }^{\mathrm{TM}}$ (30\% ferrugineol $+5 \%$ cypermethrin) to the base of the palm with a caulking gun @ 400 dollops per ha), (Faleiro, et al., 2016a). Attractiveness and killing of RPW adults were recorded throughout the experimental period of 23 weeks, in $10 \%$ of the points set in four-window bucket containers closed with a lid. The traditional food-baited RPW pheromone traps were set at 1trap/ha in A\&K treated plot (10ha) and also in a control plot (8ha) without A\&K.

A total of 209 weevils were attracted and killed by just $10 \%$ of the points in the A\&K treated plot with Hook$\mathrm{RPW}^{\mathrm{TM}}$. Also, the mean trap captures in RPW pheromone traps set in the experimental plot was significantly lower as compared to captures in the control plots with no A\&K treatment, clearly indicating that the A\&K system removed a large number of weevils in the A\&K treated plot (Faleiro, et al., 2016a).

With respect to Smart Ferrolure ${ }^{\mathrm{TM}}$, two A\& K systems of 'Smart Ferrolure ${ }^{\mathrm{TM}}$ ' from Chem Tica International, Costa Rica viz. i) a card A\&K device and ii) paste formulation, were tested in RPW infested date plantations of Al-Ahsa, Saudi Arabia on 01 September to 23 November, 2015 and 06 September to 02 December, 2015, respectively (Faleiro et al., 2016b). The card A\&K device [card: wax with 5\% cypermethrin + ferrolure $700 \mathrm{mg}+$ ethyl acetate (weevil magnet $\left.{ }^{\mathrm{TM}}\right)$ ] was installed in the field (2ha) at a density of 30 points/ha (Faleiro et al., 2016b). The paste formulation [15\% ferrugineol $+5 \%$ cypermethrin] was deployed in a 3 ha plantation as a 3g dollop @ 250points/ha.
The dead weevils in the points set in containers in the trial sites revealed that both the card device and paste formulation of Smart Ferrolure ${ }^{\mathrm{TM}}$ attracted and killed RPW adults. However, the paste formulation killed significantly more weevils (16 weevils in only $10 \%$ A\&K points) as evidenced from the dead weevils in the containers as compared to the card system (only 9 weevils in $50 \%$ of the points). While results with the paste were encouraging, the card exhibited significantly low killing capacity in about 45 days after exposure in the field, probably due to accumulation of dust on the card that prevented contact of attracted weevils to the insecticide.

In India, both the above card device and paste formulation of 'Smart Ferrolure ${ }^{\mathrm{TM}}$ ', by Chem Tica International, Costa Rica were tested in two field trials from 01 September, 2015 to 09 April, 2016 in the same RPW infested oil palm plantation belonging to Godrej Agrovet Limited, Valpoi, Goa, India. Each A\&K system (paste and card) was tested in 8 ha (Faleiro et al., 2016b). In these trials, $15 \%$ of the points were set in open containers to record weevil that get attracted and killed. In all the trial sites in Saudi Arabia and India a trap density of 1trap/ha was maintained and other routine RPW-IPM practices carried out.

From the trial in the oil palm plantation in India with Smart Ferrolure ${ }^{\mathrm{TM}}$ (Figure 2), it is evident that the paste formulation of Smart Ferrolure ${ }^{\mathrm{TM}}$ was superior as compared to the card system. RPW population reduced by $89 \%$ at the end on trial-II using the paste formulation of Smart Ferrolure $^{\mathrm{TM}}$ as compared to the card system where adult population reduced by only $41 \%$ (Faleiro et al., 2016b).

Dry Trap - Weevil captures in two field trials revealed that the treatments (Picusan Trap ${ }^{\mathrm{TM}}$, Electrap ${ }^{\mathrm{TM}}$ and the traditional bucket trap) were statistically similar (Al-Saroj et al., 2017). However, recent report (Kharrat et al., 2018) based on trials carried out against $R$. palmarum, indicated 
that the attraction may be due to the pheromone/synthetic attractant rather than electro-magnetic radiation, which is contrary to the claim that the functioning of the Electrap ${ }^{\mathrm{TM}}$ is based on the concept that insect communication is mediated by radiation. This mechanism of electromagnetic communication and olfaction in insects has been previously reported by several workers (Laithwaite, 1960; Callahan, 1965).

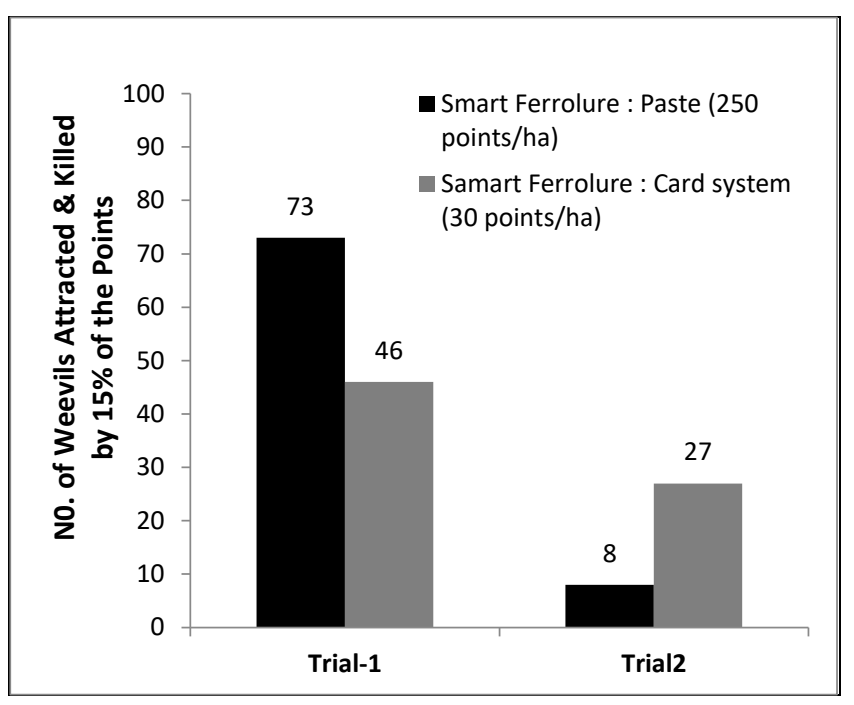

Figure 2. RPW Attracted \& Killed by Smart Ferrolure ${ }^{\mathrm{TM}}$ tested on Oil Palm [01 September, 2015 to 09 April, 2016]: Goa, India. Trial-I: 01 September-30 November, 2015; Trial2: 10 January-9 April, 2016 (Source: Faleiro et al., 2016b).

RPW Repellents - A push-pull strategy deployed in combination with a repellent and attractant has been proven useful for the management of several species of bark beetles (Borden et al., 2006) and needs to be tested against RPW.

Replicated field trials were carried out in Al-Ahsa between 2011 and 2012 to screen 45 know insect repellents through trap shut down studies. Four promising repellents identified (GCC patent pending) in these trials were further tested for tree protection in a 10 ha RPW infested date plantation where these repellents were installed at 50 repellents/ha, while RPW pheromone traps set at 1 trap/ha were installed at the periphery of the test plot in a push-pull design. A control plot (10 ha) without the repellent was also maintained and weevil captures in the treated and control plot were compared at the end of the experimental period (April-July 2014). In addition to the above, replicated field trials were also carried out in Al-Ahsa to ascertain the repellent potential of verbenone against RPW through trapshut down studies (Faleiro, 2016).

Four RPW repellents were identified through trap shutdown studies with over $80 \%$ trap shut down (Faleiro, 2012). The repellents are currently being vetted for a GCC patent. Furthermore, upon testing of these repellents in a push pull system, weevil captures in plots with pheromone traps treated with the repellent recorded higher weevil captures indicating that the pest was repelled from the repellent treated plot but weevil captures in traps were statistically similar in plots without the repellent. It may be necessary to increase the repellent density per unit area from the 50 repellents/ha tested to obtain adequate repellency effect. Trials with verbenone against RPW resulted in $75 \%$ trap shut down. Further testing of these RPW repellents for palm protection is required (Faleiro, 2016). Testing RPW repellents with the service less Electrap ${ }^{\mathrm{TM}}$ or $\mathrm{A} \& \mathrm{~K}$ technology in a push-pull system also needs to be evaluated.

\section{Conclusion}

RPW adults attracted and killed by both Hook-RPW ${ }^{\mathrm{TM}}$ and Smart Ferrolure ${ }^{\mathrm{TM}}$ in the above trials clearly indicates that a trap density of 1 trap/ha was not sufficient in trapping the adult weevils in the test plantations. Pheromone trap densities in area-wide RPW-IPM programs range from one to 10 traps per hectare (Faleiro et al., 2011; Oehlschlager 2006; Soroker et al., 2005;). However, increasing the trap density is often not possible due to the periodic servicing (change of food bait and water), necessary to sustain the trapping efficiency. In this context, the 'trap and bait free' A\&K option could significantly augment the mass trapping programme of RPW by killing the emerging adult weevil population in the field. A\&K technology can successfully eliminate adult RPW population. The technology serves as an excellent tool to manage RPW population where infestations are high, or in plantations that are inaccessible and neglected and could significantly strengthen the ongoing pheromone trap based RPW-IPM strategy particularly in plantations where the pheromone trap density has to be increased to effectively mass trap the adult population. The cost involved in the periodic servicing associated with the traditional food-baited pheromone traps is effectively eliminated with this 'bait and trap free' technique of controlling the adult RPW population in the field. However, a minimum of one food baited pheromone trap/ha is required to be maintained in an area-wide RPW control programme to gauge weevil activity in the field. Furthermore, A\&K has the potential to do away with the need to take up routine periodic preventive insecticide sprays. The technique has been used in RPW-IPM programs in date palm, the canary palm and coconut in Mauritania, Abkhazia in the Republic of Georgia and Malaysia, respectively.

All safety precautions (wearing of gloves, mask, foot wear, etc.) need to be complied with while applying RPW A\&K formulation in the field. In case of allergic reaction or coming in direct contact with the product, further application should be stopped, immediate medical assistance sought and the manufacturer contacted.

The Electrap ${ }^{\mathrm{TM}}$ is an efficient service free semiochemical mediated technology against RPW and can be incorporated in RPW-IPM programs. However, known RPW repellents need further testing to be incorporated in an RPW-IPM program involving a push-pull strategy. 
الملخص

فاليرو، جو رومينو، عبد المنعم الثواف، حمدتو عبد الفراج الثفيع وسمير باي رايكر. 2019. دراساتُّ لتقتيات تعتمد على كيميائيات الاتصال ولا

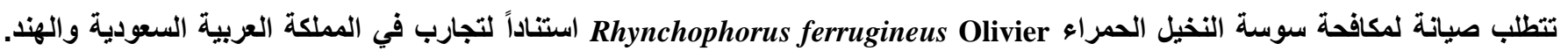
مجلة وقاية النبات العربية، 31(2): 142-136.

تعدّ سـوسـة النخيل الحمراء

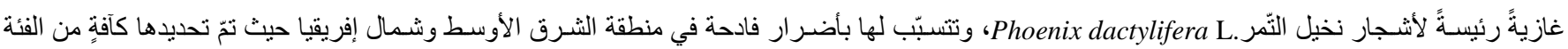

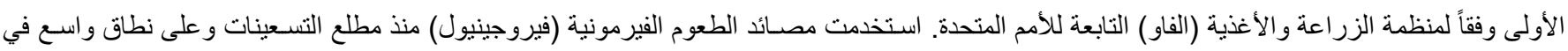

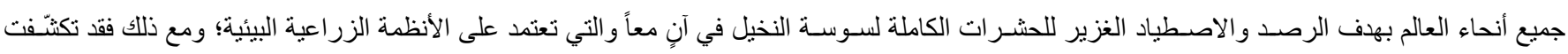

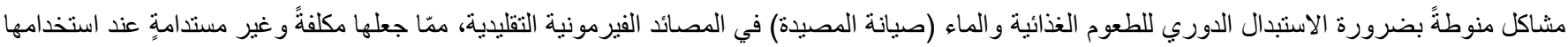

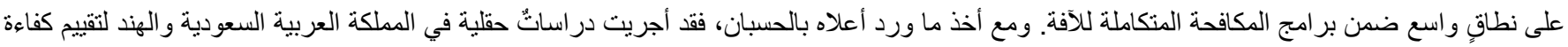

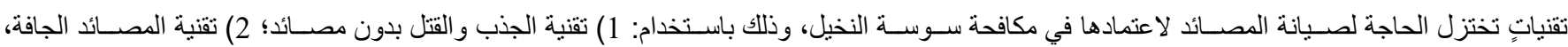

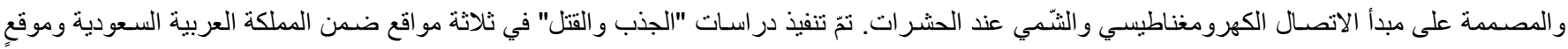

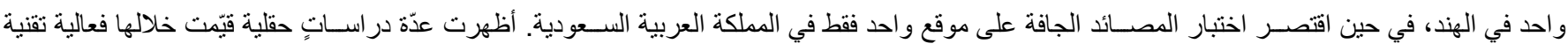

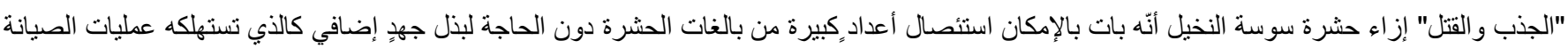

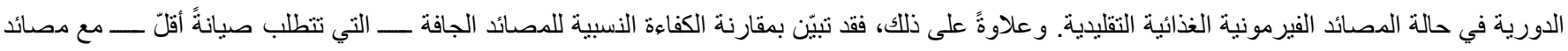

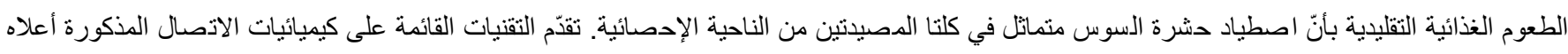

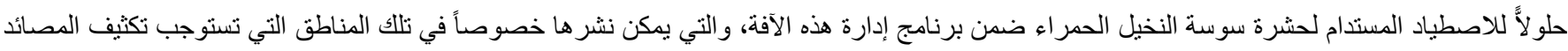

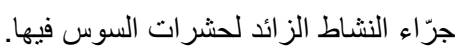
كلمات مفتاحية: سوسة النخيل الحمر اء، كيميائيات الاتصال، الجذب و القتل، مصيدة جافة، طاردات.

\section{References}

Abraham, V.A. and C. Kurian. 1975. An integrated approach to the control Rhynchophorus ferrugineus $\mathrm{F}$. the red weevil of coconut palm. Proceedings, $4^{\text {th }}$ Session of the FAO Technical Working Party on Coconut Production, Protection and Processing, 14-25 September, Kingston, Jamaica.

Abraham, V.A., M.A. Al-Shuaibi, J.R. Faleiro, R.A. Abozuhairah and P.S.P.V. Vidyasagar. 1998. An integrated management approach for red palm weevil, Rhynchophorus ferrugineus Oliv., a key pest of date palm in the Middle East. Sultan Qaboos University Journal for Scientific Research, Agricultural Science 3: 77-83.

Abozuhairah, R.A., P.S.P.V. Vidyasagar and V.A. Abraham. 1996. Integrated management of red palm weevil, Rhynchophorus ferrugineus $\mathrm{F}$. in date palm plantations of the Kingdom of Saudi Arabia. XX International Congress of Entomology, Florence, Italy, August 25-31, 1996. Tropical Entomology (Sect.). Paper 17-033

Aldhryhim Y.N. and H.Y. Al-Ayedh. 2015. Diel flight activity patterns of the red palm weevil (Coleoptera: Curculionidae) as monitored by smart traps. Florida Entomologist, 98: 1019-1024.

Al-Dosary, N.M., S. Al-Dobai and J.R. Faleiro. 2016. Review on the Management of Red Palm Weevil Rhynchophorus ferrugineus Olivier in Date Palm
Phoenix dactylifera L. Emirates Journal of Food and Agriculture, 28: 34-44.

https://doi.org/10.9755/ejfa.2015-10-897

Al-Saroj, S., E. Al-Abdallah, A.M. Al-Shawaf, A.M. AlDandan, I. Al-Abdullah, A. Al-Shagag, Y. AlFehaid, A. Ben Abdallah and J.R. Faleiro. 2017. Efficacy of bait free pheromone trap (ElectrapTM) for managementof red palm weevil, Rhynchophorus ferrugineus (Olivier) (Coleoptera: Curculionidae). Pest Management in Horticultural Ecosystems, 23: 55-59.

Borden, J.H. 1985. Aggregation pheromones. In: Comprehensive Insect Physiology, Biochemistry and Pharmacology. G.A. Kerkut and L.I. Gilbert (eds). Pergamon Press, Oxford, 9: 257-285.

Borden, J.H., A.L. Birmingham and J.S. Burleigh. 2006. Evaluation of the push-pull tactic against the mountain pine beetle using verbenone and non-host volatiles in combination with pheromone-baited trees. Forestry Chronicle, 82: 579-590.

Camelo, L.A., P.J. Landolt and R.S. Zack. 2007. A kairomone based attract-and-kill system effective against alfalfa looper (Lepidoptera: Noctuidae). Journal of Economic Entomology, 100: 366-374.

Callahan, P.S. 1965. Intermediate and far infrared sensing of nocturnal insects. Part I. Evidences for a far infrared (FIR) electromagnetic theory of communication and sensing in moths and its relationship to the limiting 
biosphere of the corn earworm, Heliothis zea. Annals of the Entomological Society of America, 58:727-45.

Dembilio, O. and J.A. Jacas. 2012. Bio-ecology and integrated management of the red palmweevil, Rhynchophorus ferrugineus (Coleoptera: Curculionidae), in the region of Valencia (Spain). Hellenic Plant Protection Journal, 5: 1-12.

El-Sayed, A.M., D.M. Suckling, J.A. Byers, E.B. Jang and C.H. Wearing. 2009. Potential of "lure and kill" in long-term pest management and eradication of invasive species. Journal of Economic Entomology,102: 815-835. https://doi.org/10.1603/029.102.0301

El-Shafie, H.A.F. and J.R. Faleiro. 2017. Optimizing components of pheromone-baited trap for the management of red palm weevil, Rhynchophorus ferrugineus (Coleoptera: Curculionidae) in date palm agroecosystem. Journal of Plant Diseases and Protection, 124: 297-287. https://doi.org/10.1007/s41348-017-0097-5

El-Shafie, H.A.F., J.R. Faleiro A.H. Al-Abbad L. Stoltman and A. Mafra-Neto. 2011. Bait-Free Attract and Kill Technology (Hook ${ }^{\mathrm{TM}}$ RPW) to Suppress Red Palm Weevil, Rhynchophorus Ferrugineus (Coleoptera: Curculionidae) in Date Palm. Florida Entomologist, 94: 774-778.

Faleiro, J.R., P.A. Rangnekar and V.R. Satarkar. 2003. Age and fecundity of female red palm weevils Rhynchophorus ferrugineus (Olivier) (Coleoptera: Rhynchophoridae) captured by pheromone traps in coconut plantations of India. Crop Protection, 22: 9991002.

Faleiro, J.R. 2006. A review of the issues and management of the red palm weevil Rhynchophorus ferrugineus (Coleoptera: Rhynchophoridae) in coconut and date palm during the last one hundred years. International Journal of Tropical Insect Science, 26: 135-150.

Faleiro, J.R., M.A. El-Saad and A.H. Al-Abbad. 2011. Pheromone trap density to mass trap Rhynchophorus ferrugineus (Coleoptera: Curculionidae/ Rhynchophoridae/ Dryophoridae) in date plantations of Saudi Arabia. International Journal of Tropical Insect Science, 31: 75-77.

Faleiro, J.R. 2012. Final Report- ARAMCO funded red palm weevil project "Developing Red Palm Weevil (RPW) Rhynchophorus ferrugineus (Olivier) IPM Technology in Date Palm Agro-Ecosystems of Saudi Arabia" (2010-1012) at the Date Palm Research Centre of Excellence, King Faisal University, Al Hassa, Saudi Arabia. 96 p.

Faleiro, J.R. 2016. Final Report (End of Assignment Report), submitted to FAO, Saudi Arabia on completion of the long-term FAO assignment (February, 2013 to July 2016) in the FAO Projects UTF/SAU/043/SAU \& UTF/SAU/038/SAU: 41 p.

Faleiro J.R., A.M. Al-Shawaf, A.M. Al-Dandan, A. AlOdhayb, A. Al-Rudayni, A.B. Abdallah, M.P. Peixoto, R. Vargas, M. Bottom, S. Chidi, R. Borges and A. Mafra-Neto. 2016a. Controlled Release Products for Managing Insect Pests. Outlooks on Pest Management, 27: 175-180.
Faleiro, J.R., A.M. Al-Dandan, S. Pai Raikar, A. Ben Abdallah, I. Al-Abdullah and A.L. Gadi. 2016b. Attract and Kill Technology to Control Red Palm Weevil: Experiences on Date Palm in Saudi Arabia and Oil Palm in India. Invited Talk presented at the 'Scientific Seminar during the $2^{\text {nd }}$ Egyptian Date Palm Festival in Siwa, Egypt, 27-29 October, 2016.

FAO, 2017. FAO multi-disciplinary and multi-regional strategy for the management of red palm weevil. http://www.fao.org/3/a-ms665e.pdf (accessed on 15 November, 2018)

Giblin-Davis, R.M., J.R Faleiro, J.A. Jacas, J.E. Peña and P.S.P.V. Vidyasagar. 2013. Coleoptera: Biology and management of the red palm weevil, Rhynchophorus ferrugineus. Pages 1-34. In: Potential Invasive Pests of Agricultural Crop Species. J.E. Peña (ed.). CABI Wallingford, UK.

Guarino S., E. Peri, P.L. Bue, M.P. Germanà, S. Colazza, L. Anshelevich, U. Ravid and V. Soroker. 2013. Assessment of synthetic chemicals for disruption of Rhynchophorus ferrugineus response to attractantbaited traps in an urban environment. Phytoparasitica, 41: 79-88.

Hallett, R.H., G. Gries, R. Gries, J.H. Borden, E. Czyzewska, A.C. Oehlschlager, H.D. Pierce Jr., N.P.D Angerilli and A. Rauf. 1993. Aggregation pheromones of two Asian palm weevils, Rhynchophorus ferrugineus and Rhynchophorus vulneratus, Naturwissenschaften, 80: 328-331. https://doi.org/10.1007/BF01141908

Hallett, R., A. Oehlschlager and J. Borden. 1999. Pheromone trapping protocols for the Asian palm weevil, Rhynchophorus ferrugineus (Coleoptera: Curculionidae). International Journal of Pest Management, 45: 231-237. https://doi.org/10.1080/096708799227842

Kharrat S., F. Gonzalez, C. Rodriguez, C. Calvo and A.C. Oehlschlager. 2018. Recent advances in palm weevil trap and lure design and A\&K techniques for RPW. Presented at the International Scientific Meeting on 'Innovative and sustainable approaches to control the Red Palm Weevil', CIHEAM Bari, 23-25 October 2018, Organized by FAO and CIHEAM Bari, Italy.

Horowitz, R., P.C. Ellsworth and I. Ishaaya. 2009. Biorational pest control-An overview. In: Biorational Control of Arthropod Pests. I. Ishaaya and A.R. Orowitz (eds.). Springer Science + Business Media B. V. 2009. https://doi.org/10.1007/978-90-481-2316-2_1

Hossain, M.S., D.G. Williams, C. Mansfield, R.J. Bartelt, L. Callinan and A.L. Il'chev. 2005. An attract-andkill system to control Carpophilus spp. in Australian stone fruit orchards. Entomologia Experimentalis et Applicata, 118: 11-19.

Laithwaite, E.R. 1960. A radiation theory of the assemblin g of moths. The Entomologist, 93 (1165): 1-5

Marfa-Neto, A., C.J. Fettig, A.S. Munson, C.RodriguezSaona, R. Holdcraft, J.R.Faleiro, H. El-Shafie, M.Reinke, C. Bernardi and K.M. Villagran. 2014. Development of Specialized Pheromone and Lure Application Technologies (SPLAT®) for Management 
of Coleopteran Pests in Agricultural and Forest Systems (Chapter 15). Pages: 211-242. In: "Biopesticides: State of the Art and Future Opportunities". A. Gross, J. Coats, J. Beck and S. Duke (eds.), ACS Symposium Series, American Chemical Society. Washington, DC. 279 p.

Mazomenos, B.E., A. Pantazi-Mazomenou and D. Stefanou. 2002. Attract and kill of the olive fruit fly Bactrocera oleae in Greece as a part of an integrated control system. IOBC (West Palearctic Regional Section) Bulletin, 25: 1-11.

Morrison, W.R., D.H. Lee, D.S. Brent, A. Khrimian and T.C. Leskey. 2015. Establishing the behavioral basis for an attract-and-kill strategy to manage the invasive Halyomorpha halys in apple orchards. Journal of Pest Science, 89: 81-96.

Milosavljević, I., H.A.F. El-Shafie, J.R. Faleiro, C.D. Hoddle, M. Lewis and M.S. Hoddle. 2019. Palmageddon: the wasting of ornamental palms by invasive palm weevils, Rhynchophorus spp. Journal of Pest Science, 92: 143-156.

Oehlschlager, A.C. 2006. Mass trapping as a strategy for management of Rhynchophorus palm weevils, I Jornada Internacional sobre el Picudo Rojo de las Palmeras. Pages 143-180.
Oehlschlager, A.C. 2016. Palm Weevil PheromonesDiscovery and Use. Journal of Chemical Ecology, 42: 617-630.

Soroker, V., D.A. Blumberg, M. Haberman, S. Hamburger-Rishard, S. Reneh, L. Talebaev, L. Anshelevich and A.R. Harari. 2005. Current status of red palm weevil infestation in date palm plantations in Israel. Phytoparasitica, 33: 97-106.

Soroker, V., A. Harari and J.R. Faleiro. 2015. The role of semiochemicals in date pest management. In Sustainable Pest Management in Date Palm: Current Status and Emerging Challenges. W. Wakil, J.R. Faleiro and T. Miller (eds.). Sustainability in Plant and Crop Protection (Book Series). Springer, 445 p.

Vacas, S., O. Melita, A. Michaelakis, P. Milonas, R. Roxana Minuz, P. Riolo, M.K. Abbass, P.L. Bue, S. Colazza, E.Peri, V. Soroker, Y. Livne, J. Primo and V. Navarro-Llopis. 2016. Lures for red palm weevil trapping systems: aggregation pheromone and synthetic kairomone. Pest Management Science, 73: 223-231

Wyatt, T.D. 2003. Pheromones and Animal Behaviour: Communication by Smell and Taste. Cambridge University Press, UK. 391 p. 